\title{
Katarzyna Kuczyńska-Koschany Dwa paradygmaty samobójstwa czy dwa akty wolnej śmierci? Heinrich von Kleist i Jean Améry
}

\begin{abstract}
Kuczyńska-Koschany Katarzyna, Dwa paradygmaty samobójstwa czy dwa akty wolnej śmierci? Heinrich von Kleist i Jean Améry [Two paradigms of suicide or two acts of voluntary death? Heinrich von Kleist and Jean Améry]. „Przestrzenie Teorii” 18. Poznań 2012, Adam Mickiewicz University Press, pp. 11-26. ISBN 978-83-232-2479-2. ISSN 1644-6763.

I compare the suicide deaths of Heinrich von Kleist and Jean Améry (Hans Mayer). I discuss the issue of suicide, considering it as a category of the German language and distinguish the difference between the terms 'Selbstmord' [self-annihilation] and 'Freitod' [self-inflicted death, voluntary death]. By comparing the two suicides committed on the two verges of modernity (the beginning of $19^{\text {th }}$ century in Berlin and $20^{\text {th }}$ century after Auschwitz), I try to describe them as an experience of the imagination (in the words of Stefan Chwin) and as a specific act of creation: a choice of a voluntary death. Suicide, comprehended as a confirmation of our existential freedom, was a deviation from what was considered the norm in Prussia in 1811 and did not seem possible as anything else than an act of despair, when committed by a death camp survivor. However, Heinrich von Kleist and Jean Améry have set a precedent in the existing cultural and historical paradigms of suicide.
\end{abstract}

Myśl, że mamy się zabić, robi nam dobrze. Żaden temat nie daje większego wytchnienia; zająwszy się nim, wnet zaczynamy oddychać. [...] Ileż to razy powtarzałem sobie, że gdyby nie myśl o samobójstwie, zabiłbym się natychmiast*.

Émile Cioran

\section{Niuanse semantyczne, dystynkcje kulturowe}

Ponieważ mowa będzie o dwóch pisarzach języka niemieckiego ${ }^{1}$, trzeba najpierw zapisać diametralną różnicę $\mathrm{w}$ postrzeganiu aktu odbierania sobie życia, jaka zachodzi między polszczyzną a niemczyzną. Po

* É. Cioran, Zły demiurg, przeł. I. Kania, Kraków 1995, s. 47-48.

1 Uprzedzając wątpliwość na temat ahistorycznego charakteru czynionych tu rozważań porównawczych, przypomnę, że Heinrich von Kleist żył w czasach, gdy otwierał się nawias asymilacji Żydów niemieckich, czasach wstępującej haskali (o czym świadczy, między innymi, salon berliński Rahel Varnhagen, zaprzyjaźnionej z Kleistem i wieloma innymi artystami przełomu XVIII i XIX wieku), a Jean Améry (Hans Mayer) - w okresie tragicznie zamykającego się nawiasu tej asymilacji, kiedy niemieccy i austriaccy Żydzi ostatecznie pozbywali się złudzeń (zmiana nazwiska, emigracja, getta, śmierć w obozach 
polsku ktoś się zabija, czyli popełnia samobójstwo. Po niemiecku istnieją aż cztery określenia tej autodestrukcyjnej czynności: neutralne, najbliższe w nienacechowaniu polskiemu samobójstwu, Selbsttötung (dosłownie: uśmiercenie samego/samej siebie); naukowe, socjologiczne Suizid (to internacjonalizm, podobny do francuskiego czy angielskiego słowa, od niego pochodzi nazwa dziedziny badań - suicydologii); Selbstmord najbardziej radykalne, drastyczne, wartościujące negatywnie sam akt (jako zbrodnię przeciwko sobie, morderstwo samego/samej siebie); wreszcie Freitod, czyli wolna śmierć - będę upierać się przy takim właśnie przekładzie tego niemieckiego złożenia, innym od zaproponowanego przez Bogdana Barana, tłumacza książki Jeana Améry'ego Podnieść na siebie rękę. Dyskurs o dobrowolnej śmierci (Hand an sich legen. Diskurs über den Freitod).

W przedmowie do tej książki różnicuje zresztą Baran niemieckie określenia samobójstwa, na temat Freitod pisząc: „dosłownie: wolna śmierć, tj. śmierć dobrowolna, z wyboru”, i nieco dalej: „Freitod ma w sobie egzystencjalną wolność" (JA, 11). Śmierć z własnej woli, z wybo$\mathrm{ru}$, śmierć mająca w sobie rys egzystencjalnej wolności, nie musi być śmiercią dobrowolną (z dobrej woli - dobrowolnie można komuś ustąpić miejsca, zrzec się splendoru, podzielić się racją żywnościową, oddać nerkę, złożyć przyrzeczenie, wreszcie - położyć na szali swoje życie zamiast czyjegoś). Niemieckie słowo Freitod nie sugeruje dobrowolności wyboru, tego, kto się zabija, sugeruje wolność, poszukiwanie wolności (cheminement). Nie dobra (lub zła) wola jest tutaj źródłosłowem, lecz wolność bez przymiotników. Być może wolność rozumiana jak przeciwieństwo konieczności, losu - tak zabił się Sokrates, jego śmierć to Freitod; być może wolność pojmowana jako dopełnienie godności - tak zabił się w warszawskim getcie dziadek Michała Głowińskiego, Lajzer³. Być może pomiędzy określeniami: Freitod Améry'ego i „eigener Tod” Rilkego istnieje subtelna relacja synonimiczna (Rilke należał do najważniejszych, choć krytycznie

zagłady) co do możliwości koegzystencji. (Świadczy o tym dobitnie chociażby dziennik Victora Klemperera.) „Sprawdzam” zatem sytuację antropologicznie paradygmatyczną sytuację decyzji o popełnieniu samobójstwa - niejako na biegunach, u źródeł nowoczesności sensu largo i,150 lat później, podczas jej najgroźniejszej zapaści. Ani w Prusach roku 1811, ani w Europie po Auschwitz nie istniała norma samobójstwa jako wolnego egzystencjalnego wyboru śmierci.

2 B. Baran, Przedmowa do wydania polskiego, [w:] J. Améry, O starzeniu się. Bunt i rezygnacja. Podnieść na siebie rękę. Dyskurs o dobrowolnej śmierci, przeł. i przedmową opatrzył B. Baran, Warszawa 2007, s. 10. Dalej stosuję skrót JA, wraz z numerem strony.

3 M. Głowiński, Czarne sezony, Kraków 2002, s. 35-41 (rozdział: Samobójstwo dziad$k a)$. Na s. 39 czytam: „W tym czasie koniec znaczył naprawdę koniec. W tej materii trudno było o wątpliwości. Przyspieszenie własnego końca było aktem wolności, wówczas niemal jedynym możliwym. I mój dziadek w konającym getcie takiego wyboru dokonał”. 
weryfikowanych, poetów autora Jenseits von Schuld und Sühne), tyle że agnostyk Améry (czy nawet ateista) nie modli się do Boga o dar „własnej śmierci”; dla niego „własna śmierć” to śmierć sobie własnoręcznie zadana, nie otrzymana $\mathrm{z}$ rąk Boga, losu ani (zwłaszcza) nazistów. Bo słowo Freitod - w przeciwieństwie do Selbstmord - było zakazane w języku Trzeciej Rzeszy 4 .

\section{Jedno "jak"}

20 listopada 1811 roku, w środę, Adolfina Henrietta Vogel i Heinrich von Kleist zjawili się nad jeziorem Wannsee, niedaleko Berlina. Zatrzymali się w zajeździe „Pod nowym dzbanem”, nie opodal Poczdamu, u niejakiego Stimminga, który następnego dnia zeznawał:

[Rankiem - K.K.K.] [...] wyszli przed gospodę [po wypiciu bulionu i kawy K.K.K.], rozmawiali o pięknym położeniu i malowniczej okolicy, a tak przy tym wyglądali weseli i rozbawieni, że nikt by nie mógł po nich niczego niezwyczajnego zauważyć. [...]

Niezadługo oboje weszli do kuchni i pani zwróciła się do mojej żony z pytaniem, czyby nie można podać im kawy po przeciwległej stronie jeziora, tam, gdzie ta piękna zielona polanka. Bo tam taki cudowny widok. Żona moja była trochę zaskoczona, bo to daleko, ale pan bardzo grzecznie dodał, że gotowi są oczywiście za fatygę dopłacić i poprosił jeszcze o rum za osiem groszy.

Następnie oboje państwo skierowali się w stronę tej polany, kiedy zaś moja żona oświadczyła, że sprzątnie ich pokoje, powiedzieli, że sobie tego nie życzą, woleliby, żeby wszystko zostało jak jest. Pani niosła koszyczek nakryty białą chusteczką, najpewniej ukryte tam były pistolety.

Kiedyśmy im tam podali kawę i rum, poprosili o stolik i dwa krzesła. Kazaliśmy im je tam zanieść. Wtedy pan poprosił o ołówek i spytał, ile winien jest nam za kawę. Przyszło nam na myśl, że to może jakiś artysta i chce namalować obraz tej okolicy. Kiedym posłał dziewczynę z ołówkiem, kazałem jej im powiedzieć, że mi nie spieszno z tym rachunkiem za kawę, ale oni oboje wyszli kilka kroków naprzeciw służącej i pani oddała jej naczynia od kawy, a w jednej z filiżanek leżały już pieniądze.

Pani powiedziała jej: „Te cztery grosze to dla was za fatygę, reszta dla gospodarza... Proszę umyć filiżankę i przynieść mi ją tu z powrotem”. Gdy dziewczyna odeszła, oboje zawrócili znów w stronę stolika.

${ }^{4} \mathrm{Na}$ ten temat pisał Stefan Chwin: „Z pewnością bardzo istotne [...] byłoby ustalenie, jak samobójca nazywa samobójstwo, to znaczy z jakich określeń o znaczeniu ustabilizowanym w kulturze korzysta. Psychologiczna treść wewnętrznego świata samobójstwa zależy też od tego, w jakim języku samobójca identyfikuje symbolicznie swój czyn. Co innego popełnić „Selbstmord”, co innego „Freitod” (słowo to było „zakazane” przez nazistów). S. Chwin, Samobójstwo jako doświadczenie wyobraźni, Gdańsk [b.d.w.], s. 422-423, przyp. 7 do rozdziału Chronologia przyczyn czy semantyzacja śmierci? 
Służąca nie zdążyła ujść więcej niż jakieś czterdzieści kroków, gdy usłyszała wystrzał. Po dalszych trzydziestu krokach dobiegł ją odgłos drugiego. Pomyślała sobie, że to pewnie ci państwo zabawiają się strzelaniem, bo oboje byli cały czas tacy weseli, pełni życia, ciskali kamyki do jeziora, skakali, żartowali.

Nam się od razu wydało jakieś dziwne, że prosili o odniesienie filiżanki, chociaż nie mieli już kawy. Ale posłaliśmy służącą, żeby im tę filiżankę odniosła.

Kiedy doszła na miejsce, znalazła ich oboje bez życia, leżeli we krwi.

Osłupiała ze zgrozy, popędziła co tchu z powrotem do gospody i w biegu zawołała do napotkanej dziewczyny: „Goście się zastrzelili, leżą tam nieżywi!”.

$\mathrm{Na}$ tę wieść wszyscyśmy oniemieli ze zdumienia. Wbiegamy natychmiast na piętro do ich pokoi. Wszystkie drzwi zamknięte na głucho. Bocznymi drzwiami przedostajemy się do jednego z pokoi. Patrzymy: drzwi zatarasowali wszystkimi znajdującymi się tam krzesłami; nic nie zostawili poza zapieczętowaną paczką.

Biegniemy wszyscy na polanę; tam zobaczyliśmy trupy obojga. Pani leżała w rozpiętym płaszczu z rozchylonymi połami, głowę miała odrzuconą do tyłu, ręce skrzyżowane na piersiach. Kula przebiła lewą pierś i serce na wylot i wyszła z tyłu pod łopatką. Pan klęczał tuż przed panią. Pozbawił się życia, strzelając sobie w głowę przez usta. Ich twarze nie były zmienione, oboje wydawali się spokojni i pogodni ${ }^{5}$.

Samobójców pochowano w osobnych trumnach, choć we wspólnej mogile, 22 listopada wieczorem.

Kilka miejsc z zeznania karczmarza zasługuje na komentarz. Najpierw dostrzeżenie precyzji przygotowanego aktu. Nie dokonują go ludzie zrozpaczeni (chociaż ona jest chora na raka $^{6}$, on nie ma $\mathrm{z}$ czego żyć), nie wybierają dlań przestrzeni z toposu locus horridus; wręcz przeciwnie - polana, otwarta przestrzeń, jasny dzień to domena tego, co zwykliśmy w topice śródziemnomorskiej określać jako locus amoenus (miejsce przyjemne). Sceneria jak z sielanki albo przedsionek łąk niebiańskich, elizejskich pól. Tak zresztą widział to sam Kleist: „My z naszej strony nie chcemy już nic wiedzieć o radościach tego świata i marzą się nam prawdziwe niebiańskie łąki i słońca, w których blasku będziemy wędrować z długimi skrzydłami u ramion"?. O tym, że byli całkowicie, bez cienia wątpliwości przekonani, że decyzję podjęli bez niczyjej presji (ani też obopólnej), świadczą listy posłane do najbliższych. Heinrich von Kleist pisał do siostry Ulryki: „Oby niebo obdarzyło cię śmiercią choćby w połowie tak

${ }^{5}$ H. von Kleist, Listy, przekł. i wstęp W. Markowska, Warszawa 1983, s. 520-522, rozspacjowania - K.K.K. Dalej stosuję skrót L, wraz z numerem strony.

${ }^{6}$ M. Brion L'Allemagne romantique: Kleist, Brentano, Wackenroder, Tieck, Caroline von Günderode, Paris 1962, s. 13 (dalej posługuję się skrótem AR, wraz z numerem strony). Autor pisał: „La rencontre d'Henriette Vogel eut donc un caractère presque providentiel; car elle savait, elle, pourquoi elle voulait mourir”.

${ }^{7}$ M. Janion, Absolut, namiętność, tragedia. Posłowie, [w:] H. von Kleist, Dramaty wybrane, przeł. J.S. Buras, Kraków 2000, s. 353 (dalej skrót MJ, wraz z numerem strony). 
pełną radości i niewypowiedzianej pogody ducha jak moja; to najserdeczniejsze moje, najgorętsze życzenie, jakie mogę Ci przesłać" $(\mathrm{L}, 516)$, tak pisał $\mathrm{w}$ liście datowanym „U Stimminga pod Poczdamem, rankiem w dniu mojej śmierci". Henrietta Vogel oznajmiała zaś w liście do Ernesta Fryderyka Peguilhena, przyjaciela rodziny, w tonacji rodem z powieści grozy, grozy niechybnie czarnej i nie całkiem prawdopodobnej: „Pańską przyjaźń, którą mnie dotychczas Pan tak wiernie darzył, muszę wystawić na pewną dziwną próbę, bo my oboje, mianowicie znany poeta Kleist i ja, znajdujemy się u Stimminga przy drodze do Poczdamu, w beznadziejnej sytuacji, leżymy tu bowiem zastrzeleni i zdani jedynie na dobroć życzliwego przyjaciela, który by nasze doczesne szczątki przekazał ziemi, tej najbezpieczniejszej twierdzy" (L, 513; wyróżnienie - H.A.V.; rozspacjowania - K.K.K.).

Czy ta piękna makabreska biograficzna nie przekracza granic naszej dzisiejszej wyobraźni, przynajmniej estetycznie? - sytuacja zastrzelonych jest rzeczywiście beznadziejna.

Współtowarzysze wolnej śmierci doskonale przewidują kolejność pośmiertnych zdarzeń: czas dotarcia posłańca do Berlina, przybycie męża Henrietty i drugiego gościa do gospody (tu zresztą wzruszająca jest troska o posiłek dla przybyszy, zawczasu zamówiony8), reakcję służącej. Przygotowując wespół swą podwójną śmierć - „Henrietta i ja, dwoje przybitych, nieszczęśliwych ludzi, którzy się zawsze uskarżali na jego [świata - K.K.K.] chłód, tak się z całego serca pokochaliśmy, a najlepszy tego dowód, że postanowiliśmy teraz wspólnie umrzeć" (pisał Kleist w liście do Sophie Müller; L, 512) - kochankowie pomyślą zresztą także o innych szczegółach. Ot, choćby o filiżance. Stanie się ona, być może, najistotniejszym rekwizytem ich śmierci, tej śmierci emblematem.

To do filiżanek trafiają tranzytowe grosze-obole dla Charona, dane dla niepoznaki służącej jako opłata za ostatnią na tym świecie wypitą kawę; paradoksalna z punktu widzenia logiki tego świata prośba o odniesienie pustej filiżanki („Nam się od razu wydało jakieś dziwne, że prosili o odniesienie filiżanki, chociaż nie mieli już kawy" - zezna Stimming), która jednak pozostaje w zupełnej zgodzie z logiką samobójców; wreszcie życzenie, wyrażone przez Henriettę Adolfinę w cytowanym już liście do przyjaciela domu: „Za 10 tal. reń., [...] prosiłabym, by Pan zamówił najpiękniejszą bladoszarą filiżankę, wewnątrz pozłacaną, obramowaną złotą arabeską na białym tle, u góry na białym polu ma być moje imię, a fason obecnie najmodniejszy. Jeśliby się Pan zwrócił z tym zamówie-

\footnotetext{
8 Podobnie późniejsza samobójczyni, poetka Sylvia Plath, jakkolwiek o wiele bardziej zrozpaczona i samotna, zatroszczy się o przygotowanie „chleba z masłem oraz dwóch kubków mleka” dla swych dzieci. Por. A. Alvarez, Bóg bestia. Studium samobójstwa, przeł. Ł. Sommer, Warszawa 1997, s. 39.
} 
niem do buchaltera Mevesa w fabryce porcelany, proszę powiedzieć mu, by tę filiżankę zapakowano i doręczono Louisowi [mężowi Henrietty K.K.K.] w wieczór wigilijny [...]" (L, 514; rozspacjowania - H.A.V.).

Trudno się dziwić, że mnie - permanentnej czytelniczce Rilkego - ta filiżanka zdała się tym dziwniejsza i tym ważniejsza, że przecież Rainer Maria, wielbiciel Kleista, odwiedzający jego samotny leśny grób, napisał w wierszu Der Tod z 1915 roku9:

Da steht der Tod, ein bläulicher Absud in einer Tasse ohne Untersatz.

Ein wunderlicher Platz für eine Tasse: steht auf dem Rücken einer Hand. Ganz gut erkennt man noch an dem glasierten Schwung den Bruch des Henkels. Staubig. Und: „Hoff-nung” an ihrem Bug in aufgebrauchter Schrift.

Das hat der Trinker, den der Trank betrifft, bei einem fernen Frühstück ab-gelesen. [...]

\section{W przekładzie Mieczysława Jastruna ${ }^{10}$ :}

Tu stoi śmierć, błękitnawy odwar $\mathrm{w}$ filiżance bez podstawki.

Niezwykłe miejsce dla filiżanki: stoi na wierzchu dłoni. Całkiem dobrze widać na polewanym smukłym kształcie odkruszenie ucha. Zakurzona. I: „Nadzieja” na jej przegubie w wyblakłym piśmie.

To przy odległym śniadaniu przeczytał pewien pijący, dla którego jest ten napój. [...]

Jedna z najwybitniejszych sawantek swej epoki, Żydówka, Rahel Levin (późniejsza Rahel Varnhagen von Ense)11, pisała po śmierci Kleista

9 R.M. Rilke, Der Tod, [w:] Gedichte. Zweiter Teil. Sämtliche Werke, hrsg. vom Rilke-Archiv in Verbindung mit Ruth Sieber-Rilke, besorgt durch Ernst Zinn, Frankfurt am Main 1987, s. 103-104.

10 R.M. Rilke, Śmierć, [w:] Poezje, wybrał, przeł. i posłowiem opatrzył M. Jastrun, Kraków 1993, s. 345.

${ }^{11}$ R. Varnhagen von Ense (19 maja 1771-7 marca 1833, ur. i zm. w Berlinie jako Rahel Levin, potem używała nazwiska Rahel Robert) prowadziła słynny (najbardziej znany obok salonu Henrietty Herz) berliński salon literacki w Berlinie na początku XIX wieku; w jej wieczorkach brali udział poeci romantyzmu niemieckiego, między innymi Heine, von Ranke, Chamisso, de la Motte Fouqué, Aleksander von Humboldt, Bettina von Arnim, Heinrich Laube. Pochodziła z bogatej berlińskiej rodziny żydowskiej, jej brat, Ludwig 
do generała pruskiego Aleksandra von der Marwitza - cytuję tę wypowiedź jako najciekawszą i najśmielszą, według mnie, wykładnię popełnionego samobójstwa:

Nie dziwi mnie czyn Kleista. Był prawy, srogi względem siebie i cierpiał wiele. Pan wie, że myślę o samobójstwie tak jak Pan. Nie uważam, by ludzie nieszczęśliwi musieli wychylać swój kielich goryczy do dna. Do istoty nieskończonej, prawdziwie wielkiej - gdy się ją pojmie - zbliżyć się można wszelkimi drogami, nie rozumiejąc żadnej. Trzeba zaufać boskiej dobroci, a czyż ta miałaby się kończyć wraz z wystrzałem z pistoletu? Wolno mi ulec wszelkiego rodzaju nieszczęściom, głupiej gorączce, kłodzie czy dachówce, spadającej znienacka, własnej niezręczności, tylko mnie samej miałoby być niedozwolone...

Rada jestem, że mój szlachetny przyjaciel - gdyż wśród gorzkich łez wspominam go jak przyjaciela - nie pogodził się z tym, co uznał za niegodne... przecierpiał wiele. Nikt z tych, którzy go teraz potępiają, nie pożyczyłby mu dziesięciu talarów, nie poświęcił nocy, nie okazał pobłażania, gdyby ośmielił zjawić się bezradny, rozstrojony. Nie wiem o jego śmierci nic oprócz tego, że najpierw zastrzelił kobietę, a potem siebie. Jest to niewątpliwie akt odwagi. Któż by nie chciał porzucić tego uprzykrzonego i niepoprawnego życia, gdyby nie bał się jeszcze bardziej mrocznych tajemnic? ${ }^{12}$.

Dla porównania: lekarze, badający zwłoki dwojga samobójców, orzekli na temat Kleista, iż był zupełnie zdrowy oraz że „był to widocznie człowiek bardzo pobudliwy, który działał pod wpływem rozstroju umysłu” (DW, 698). Mniej niż Rahel Varnhagen zda się także wiedzieć o samobójstwie Kleista Stefan Chwin. Autor książki Samobójstwo jako doświadczenie wyobraźni powiada, że w duchowym świecie niemieckiego dramaturga istotną rolę odgrywała metafora „życia jako nieciągłości”13, w rozdziale o „Poetyce” samobójstwa. Momencie „estetycznym” czynu daje taki skrócony opis aktu zgonu (bez miejsca na wyobraźnię):

Robert, był dramatopisarzem (autorem m.in. tragedii Die Macht der Verhältnisse, 1819). Karla Augusta Varnhagena von Ense (21 lutego 1785-10 października 1858), dyplomatę, pisarza, liberała, młodszego o czternaście lat, poślubiła w 1814 roku. W roku śmierci żony - 1833 - mąż wydał trzytomowy zbiór jej pism: Rahel. Ein Buch des Andenkens für ihre Freunde. W 1849 roku wyszła powieść Fanny Lewald pt. Prinz Louis Ferdinand, której główna bohaterka nosi imię Rahel. W roku 1967 ukazała się korespondencja berlińskiej sawantki. Na temat Rahel Varnhagen zob. Brockhaus-Enzyklopädie in 30 Bänden. 21., völlig bearbeitete Auflage. Band 28. F.A. Brockhaus, Leipzig-Mannheim 2006, s. 559, s.v. „Varnhagen von Ense Rahel, geb. Levin”. Por. też: H. Arendt, Rahel Varnhagen: Lebensgeschichte einer deutschen Jüdin aus der Romantik, München 2003 [1957].

12 Rachela von Varnhagen do Aleksandra von der Marwitz. Cyt. za: Listy, przeł. H. Kahanowa, [w:] H. von Kleist, Dzieła wybrane, Warszawa 1960, s. 682-683. Dalej skrót DW, wraz z numerem strony.

13 S. Chwin, Samobójstwo jako doświadczenie wyobraźni, s. 338. Dalej stosuję skrót SJDW, wraz z numerem strony. 
Kleist nad jeziorem Wannsee zjada śniadanie z kochanką, strzela jej w serce, potem strzela do siebie. Klęczą naprzeciwko siebie. Jakie znaczenie miał ten teatr śmierci - dla niej i dla niego? Czy chodziło o wykreowanie własnej romantycznej poetyki śmierci z ambicjami na legendową nieśmiertelność, czy raczej o powtórzenie cudzych wzorów umierania? Dla jednych ta śmierć była żałosną komedią romantycznego egotyzmu, dla innych wzniosłym - do łez - improwizow any m obrzędem samowolnego odejścia, wypracowanym w najdrobniejszych szczegółach.

(SJDW, 30; rozspacjowania - K.K.K.)

Chyba rzeczywiście najbliżej innego ,jak” była w swej śmiałej diagnozie Rahel Varnhagen. To jej list z 1811 roku, a nie dwieście lat późniejsze konstatacje imaginacyjno-suicydologiczne, pozwala jakkolwiek zestawiać samobójstwa Kleista i Améry'ego.

\section{Inne ,jak"}

Moja ryzykowna hipoteza brzmi: Freitod Améry'ego to antytyp śmierci, jaką umierało się w czasach nazistowskiego ludobójstwa, zwłaszcza w obozach Zagłady. O tym, czym była śmierć w Auschwitz, pisał Hans Mayer, już jako anagramowy ocalony, czyli Jean Améry, w książce Jenseits von Schuld und Sühne. Bewältigungsversuche eines Überwältigen (1966):

Tym, co działo się na samym początku, było kompletne załamanie się estetycznego wyobrażenia śmierci. Wiadomo, o czym mówię. Człowiek intelektu, a zwłaszcza intelektualista wyrosły na gruncie niemieckiego wykształcenia, nosi w sobie takie właśnie estetyczne wyobrażenie śmierci. Czerpie je z epok najdawniejszych, a już najpóźniej z okresu niemieckiego romantyzmu. Charakteryzują je mniej więcej nazwiska takie jak Novalis, Schopenhauer, Wagner, Tomasz Mann. Dla śmierci w jej literackiej, filozoficznej i muzycznej postaci nie było w Auschwitz miejsca. Nie było mostu łączącego śmierć w Auschwitz ze Śmierciqa w Wenecji. Nieznośna była wszelka poetycka reminiscencja śmierci, czy byłaby to śmierć w Lieber Bruder Tod Hessego, czy śmierć u Rilkego, który tak ją opiewał: „Każdemu daj śmierć jego własną, Panie" [przekład Jastruna - K.K.K.]. Dla intelektualisty było jasne, że estetyczne wyobrażenie śmierci stanowi część estetycznego sposobu życia: skoro zaś tego drugiego nie sposób już było sobie nawet przypomnieć, to i to pierwsze stawało się eleganckim niczym. Śmierci w obozie nie towarzyszyła słodka muzyka z Tristana i Izoldy, tylko wrzaski esesmanów i kapo. Śmierć człowieka, ponieważ była jednak jakimś wydarzeniem społecznym, które rejestrowano w tzw. oddziale politycznym formułką ,zejście śmiertelne”, w ostatecznym rozrachunku traciła także jednostkowo swój specyficzny wymiar do tego stopnia, że jej estetyczne 
upozowanie stawało się dla tego, kto się jej spodziewał, niejako bezczelnością, a dla jego towarzyszy niedoli - nieprzyzwoitością ${ }^{14}$.

Pisze dalej Améry, że w obozie najważniejsze było pytanie, jak umrę? W komorze gazowej, w bunkrze głodowym, rozstrzelany? Od zastrzyku fenolu, od uderzenia w głowę czy „na drutach”? Umieranie - pisze dalej Améry - „było wszechobecne, śmierć trzymała się w cieniu” (PWIK, 55):

I tak na przykład opowiadano sobie w obozie o pewnym esesmanie, który kiedyś rozpłatał jednemu z więźniów brzuch i wypełnił go piaskiem. Jest chyba oczywiste, że wiedząc o tego rodzaju możliwościach, człowiek już raczej nie zajmował się tym, czy albo że musi umrzeć, ale już wyłącznie tym, jak to się stanie.

(PWIK, 54, rozspacjowania - Autor)

Dlatego dla Améry'ego kwestią najważniejszą stała się po ocaleniu możliwość oddzielenia śmierci na wolności od procederu umierania: „Lecz tylko na wolności - pisał - można mieć myśli o śmierci niebędące jednocześnie myślami o umieraniu ani strachem przed umieraniem" (PWIK, 55).

Rozważanie Freitod zaczyna się u Améry'ego już w refleksjach poobozowych, bo tam po raz pierwszy - dziesięć lat przed napisaniem książki o samobójstwie - dostrzega różnicę pomiędzy aporetycznym ,jak” Zagłady a śmiercią na wolności:

Śmierć na wolności można przynajmniej na drodze rozumowej oderwać od umierania: w aspekcie społecznym, kiedy obudujemy ją rozważaniami na temat pozostałej przy życiu rodziny, zawodu, który porzucamy; $\mathrm{w}$ aspekcie myślowym, kiedy jeszcze istniejąc, staramy się wyczuć tchnienie nicości. Nie trzeba oczywiście dodawać, że takie próby nie dają żadnych efektów, ponieważ sprzeczność śmierci i tak pozostaje nierozwiązana. Tak czy inaczej jednak samo usiłowanie kryje w sobie własną godność: człowiek wolny może przybrać w obliczu śmierci konkretną postawę rozumową, ponieważ dla niego śmierć nie wyczerpuje się tylko i wyłącznie w męce umierania. Człowiek wolny może posunąć się w tym aż do granic myśli, ponieważ zawsze istnieje w nim pewna, choćby tylko mikroskopijna, wolna od strachu przestrzeń. Dla więźnia natomiast śmierć nie ma już żądła: ani takiego, które sprawia ból, ani takiego, które pobudza do myślenia.

(PWIK, 55-56; rozspacjowania - K.K.K.)

Istnieją właściwie dwie odpowiedzi na pytanie, dlaczego Améry popełnił wolne samobójstwo: socjologiczna (podurkheimowska, powiedzmy), ponieważ był pozbawiony praw przez ustawy norymberskie, więziony,

14 J. Améry, Poza wina i kara. Próby przełamania podjęte przez złamanego, przeł. R. Turczyn, posłowiem opatrzył P. Weiser, Kraków 2007, s. 53-54 (wyróżn. K.K.K.; rozspacjowanie - Autora). Dalej posługuję się skrótem PWIK, wraz z numerem strony. 
torturowany ${ }^{15}$, przeżył Auschwitz, a potem szybkie rozgrzeszenie nazizmu w Europie. I istnieje - przynajmniej hipotetycznie - jego własna odpowiedź: bo to była ostatnia przestrzeń mojej wolności. Ta śmierć konstytuowała ostatnią możliwość samoidentyfikacji. Zanim jej nie postanowił/ustanowił, takiej autoidentyfikacji nie było, nie istniała przestrzeń, w której mógłby o sobie mówić ,ja”.

Ja-Niemiec? „Piszący te słowa nie jest Niemcem i nie jemu udzielać rad temu narodowi" (PWIK, 179) - pisze Améry po niemiecku. Ja-Żyd? Ani religijnie, ani politycznie, ergo syjonistycznie, ani kulturowo - w klinczu między przymusem a niemożnością bycia Żydem ${ }^{16}$, trudno budować cokolwiek na tożsamości ofiary, „trupa na urlopie” (,To my, ofiary, będziemy tymi naprawdę niewyuczalnymi, nieprzejednanymi i we właściwym tego słowa znaczeniu reakcyjnymi wrogami historii, a fakt, że jednak niektórzy z nas przeżyli, będzie się jawił jako zwykły błąd w sztuce"; PWIK, 182-183; „Naszym jedynym prawem, jedynym obowiązkiem było samemu usunąć się z tego świata"; PWIK, 195). Ja-Belg/Francuz? (Tak wynikałoby z anagramu.) Również nie:

Wcale jednak nie stało się przez to tak, że w równym stopniu, w jakim język ojczysty stał się dla nas wrogi, język obcy stał się naszym prawdziwym przyjacielem. Zachowywał się on i zachowuje z rezerwą, pozwalając jedynie na krótkie kurtuazyjne wizyty. Zapowiadamy się u niego, comme on visite des amis, i wcale nie jest to to samo, co wpaść z wizytą do przyjaciól. La table nigdy nie będzie tym samym co stół, co najwyżej można się przy nim najeść do syta. Nawet pojedyncze samogłoski, choćby miały te same fizyczne właściwości co rodzime, były obce i takie też pozostały.

(PWIK, 128-129)

Jednak owo - ja-Żyd - w specyficznym znaczeniu okazuje się raną najgłębiej zadaną, taką, która buduje najboleśniejszą z tożsamości, tę najmocniej powiązaną z wolnością:

Jako Żyd idę przez świat niby człowiek cierpiący na jedną z tych chorób, które wprawdzie nie powodują specjalnie uciążliwych dolegliwości, zawsze jednak koń-

15 Améry uznaje tortury za kwintesencję Trzeciej Rzeszy. Pisze: „Kto doznał tortur, nie może się już zadomowić w świecie. Hańba unicestwienia nie da się już wymazać. Zaufania do świata, które wali się w gruzy po części już z chwilą otrzymania pierwszego ciosu, a całkowicie dopiero w trakcie tortur, nie da się już odzyskać. Doświadczenie współbliźniego jako antybliźniego tkwi w torturowanym w formie skumulowanego przerażenia: czegoś takiego nie da się pominąć i wybiec wzrokiem w świat, w którym rządzi zasada nadziei [E. Bloch, Das Prinzip Hoffnung, 1954-1959 - przyp. K.K.K.]. Ktoś, kogo męczono, jest bezbronnie wydany na pastwę strachu. To on właśnie obejmuje potem nad nim władzę" (PWIK, 100-101).

${ }^{16} \mathrm{Na}$ ten temat por. rozdział O przymusie i niemożności bycia Żydem (PWIK, 187-223) oraz tekst Améry'ego z 1978 roku pt. Mein Judentum (ostatnio spolszczony przez Katarzynę Kończal, Autorce przekładu bardzo dziękuję za udostępnienie go przed publikacją). 
czą się zejściem śmiertelnym. Nie zawsze na nią cierpiał. Kiedy próbuje dotrzeć do swego Ja, obierając je z kolejnych łupin cebuli jak Peer Gynt, nie odnajduje tego zła. Pierwsza szkoła, pierwsza miłość, pierwsze wiersze: wszystko to nie ma z tym nic wspólnego. Teraz jednak jest chorym, wcześniej i głębiej niż krawcem, księgowym czy poetą. Tak samo i ja jestem teraz tym, kim nie jestem, gdyż nim nie byłem, zanim się nim stałem, zwłaszcza dla innych: Żydem. Śmierć, przed którą nie zdoła ujść chory, oto moje zagrożenie.

(PWIK, 212)

Solidarność ze wszystkimi zagrożonymi w swej wolności, równouprawnieniu czy wręcz fizycznej egzystencji Żydami jest także, ale nie tylko reakcją na antysemityzm, który zdaniem Sartre’a nie jest poglądem, tylko skłonnością i gotowością do popełnienia zbrodni ludobójstwa: reakcja ta stanowi część składową mojej osoby i jest moją bronią w walce o odzyskanie godności. Dopiero wówczas bowiem, kiedy nie będąc Żydem w sensie możliwości jednoznacznej klasyfikacji jako Żyda, jestem Żydem w poznaniu i uznaniu wyroku wydanego przez świat na Żydów i wreszcie współuczestniczę w historycznym procesie odwoławczym, dopiero wówczas wolno mi wypowiadać słowo „wolność”.

(PWIK, 217-218; rozspacjowania - Autor)

Ważne, by pojąć samobójstwo, które popełnił, wydają się również słowa zapisane przez Améry'ego w eseju Über das Altern. Revolte und Resignation (1968):

„Le faux, c'est la mort”, pisze Jean-Paul Sartre. Filozof neguje w ten sposób śmierć, która czyni egzystencję nieprzenikliwą esencją, kamieniejącym „être”, który jest już tylko avoir-été. Kto zadaje się ze śmiercią, wchodzi w coś więcej niż tylko liaisons dangereuses: uprawia nieprzyzwoite kazirodztwo. Można też zasadnie powiedzieć, że jedyną prawdą jest śmierć, bo stanowi przyszłość wszelkich przyszłości. [...] Śmierć jest prakontradykcją, która jako absolutne „nie” obejmuje wszelkie inne dające się pomyśleć negacje.

(JA, 117, rozspacjowania - K.K.K.)

Wiele myślę o zaśnieżonych drogach z 1944 roku [mowa tu o marszu śmierci z Auschwitz do Buchenwaldu i Bergen-Belsen, który autor przeżył - przyp. K.K.K.] i dobrej śmierci wskutek mordu, która nie zechciała się mną zainteresować. Istotnie, trudno o piękniejszą śmierć - nie każdy ma taką szansę.

Myśl nie do przyjęcia, jeśli zważyć, jakim reakcyjnym prostactwom dałaby alibi! I co za głupota ze strachu przed umieraniem życzyć sobie już kiedyś grożącej śmierci! Jest to jednak tylko głupota kontradykcji śmierci, sprzeczności, która unieważnia wszelki namysł.

(JA, 125)

Pomiędzy I a IV wydaniem eseju o starzeniu się, pomiędzy rokiem 1968 a 1977, pojawia się tylko jedna - dla mnie jednak najważniejsza z możliwych zmian: „W jednym tylko punkcie muszę dokonać korekty, 
tam mianowicie, gdzie napisałem «błazeńskie opowiadanie o samobójstwie». Tutaj przemyślenia i doświadczenia popchnęły mnie w innym kierunku, nadały mojej refleksji wymiar, którego wówczas nie przeczuwałem”. Ta autokorekta to tak naprawdę radykalna zmiana zapatrywań na samobójstwo. Jeszcze w I wydaniu eseju Über das Altern Améry pisał:

Znamy „beztroskich” aż po późne lata i starość. [...] Są inni, nazywani niezrównoważonymi, którzy uciekają przed śmiercią w śmierć i wyobrażają sobie chyba, że samobójstwo, akt, który ich brak wolności nieodwołalnie przypieczętuje, będzie wzmocnieniem ich wolności. Możliwe, że postąpiłby tak Nietzsche, gdyby nie popadł wcześniej w chorobę psychiczną, pisał bowiem: „Jeno że jest to śmierć najnikczemniejsza, śmierć niewolna, śmierć w niewłaściwej chwili, śmierć tchórzliwa. Należałoby, z miłości do życia - pragnąć innej śmierci, wolnej, świadomej, przewidzianej, od przypadku niezależnej” [przeł. S. Wyrzykowski]. Błazeńskie opowiadanie o samobójstwie.

(JA, 128-129)

Po raz pierwszy pojawia się tu jednak odróżnienie śmierci niewolnej od wolnej, „zadanej sobie” (w dwojakim tego wyrażenia znaczeniu) od przypadkowej. Rozwinięcie tej koncepcji pojawi się w swego rodzaju Todesbrief Améry'ego, w jego eseju o samobójstwie, w którym (jak sam pisze) stara się prześledzić aporie condition suicidaire i rezygnuje $\mathrm{z}$ wszelkich „wywiedzionych ze słowa «logos» i merytorycznych pojęć” (JA, 137). Ten, kto zadaje sobie Freitod, jak ten, kto (toutes proportions gardées, oczywiście) uprawia freie Liebe, już nie potyka się o Logos.

Nie potyka się, bo odskakuje. „Kto szuka [dobro]wolnej śmierci [...], ten wyłamuje się z logiki życia” (JA, 148) - powiada Améry, i dodaje:

Oto miejsce, w którym znajdują się wszyscy, Kleist, Chatterton, Pavese, Celan, Szondi, a także niezliczona mnogość bezimiennych, wyrażających tu czynem, niezależnie od tego, czy ich przedsięwzięcie „powiodło się”, czy nie, coś głęboko tajemniczego i logicznie sprzecznego, mianowicie tezę: „życie nie jest najwyższym z dóbr".

[Przypominam dyskretnie, że mówi to ocalony z Auschwitz, ten, który przeżył tortury i marsz śmierci.] Ten ktoś zauważa: „Nie znamy bowiem bardziej dręczącej zagadki niż śmierć, a wewnątrz niej - [dobro]wolna śmierć, która ogólną kontradykcję śmierci i jej absurdalność wzmaga oraz pomnaża - poza wszelką miarę" (JA, 157).

Samobójstwo pojmuje Améry jako śmierć naturalną - „podmiot rozstrzyga w pełni suwerenności za siebie, co nie oznacza: przeciw społeczeństwu” (JA, 185). Mówi: „Głośne Nie głośnemu, niszczącemu échec życia" (JA, 185). Nienaturalne jest - zdaniem Améry'ego - życie ku śmierci. Łagodzi też freudowskie określenie „popęd” śmierci i woli mówić 
o „skłonności do śmierci” (JA, 196): „Skłonność do śmierci nie tyle się kształtuje, ile raczej trzeba ją wycierpieć, nawet jeśli to cierpienie jest ucieczką przed cierpieniami życia. Jest wklęsła, nie wypukła" (JA, 196). Ale zaraz potem przeciwstawia skłonność - decyzji.

„Samobójca [...] umiera na mocy własnej decyzji” (JA, 203). Wyznacza dzień, godzinę. Należy do siebie. „Człowiek ze swej istoty należy do siebie" - zapisuje Améry, przypomnę - torturowany, więzień Auschwitz, niedobrowolny uczestnik marszu śmierci. Odróżnia. Powiada, że samobójca nie jest mordercą samego siebie, nie uprawia odmiany autoludobójstwa. Nie jest zbrodniarzem: „Samobójcą [...] jest ktoś załatwiający własną sprawę, kto stoi poza osądem i wybaczeniem, człowiek, którego prawa do własnego życia, do własnej śmierci nie można naruszać" (JA, 218).

Samobójca jest wolny (JA, 247). Freitod oznacza drogę ins Freie, wolna śmierć jest drogą ku wolności (JA, 248).

"C'est la mort qui change une vie en destin" - mówi André Malraux. Ale ten los jest zawsze nieszczęśliwy, dodaje Améry. I domyka to spostrzeżenie piękną metaforą, dedykowaną wszystkim, co zaniechali polowań:

Polowanie zostaje przerwane, myśliwy bez zdobyczy wychodzi naprzeciw niewypowiadalnemu. I to przerwanie łowów mocą własnej decyzji nie miałoby być wolnością?

(JA, 238)

\section{Czy śmierć dwukrotnie odroczona?}

O śmierci Kleista powiadano, że była antyspołeczna; Améry, domagając się prawa do zadania sobie śmierci jako przywileju wolnego człowieka, powołuje się na nurt antypsychiatryczny (Foucaulta, Deleuze'a, Guattariego; JA, 180).

Być może ważniejsze, że była to śmierć - w obydwu przypadkach odroczona.

Kleist, uwięziony przez Francuzów w styczniu 1807 roku, na szczęście nie został uznany za szpiega (wówczas natychmiast by go rozstrzelano, wyroki wykonywano w trybie doraźnym), ale najpierw przez cztery tygodnie przebywał w Fort de Joux, nie opodal Pontarlier, a potem, przez kilka miesięcy, w obozie dla jeńców wojennych w Châlons-sur-Marne ${ }^{17}$.

17 Podaję za: P. Goldammer, Heinrich von Kleist. Mit 56 Abbildungen. VEB Bibliographisches Institut Leipzig 1980 [Bildbiographie], s. 35-36: „Anfang Januar 1807 bricht Kleist, gemeinsam mit Pfuel und zwei anderen preussischen Offizieren, aus Königsberg 
Zwolniony w lipcu 1807 roku, doświadczył jednak potrójnych krat, braku powietrza i światła.

Ocalenie Améry'ego jest jego doświadczeniem ośrodkowym, dramat ocalenia zdaje się współkreować decyzję o wolnej śmierci.

\section{Przypadek czy paradygmat?}

Czy - zabijając się tak a nie inaczej, wybierając taką a nie inną metodę, okoliczności, miejsce, czas - Heinrich von Kleist i Jean Améry są osobnymi przypadkami (w sensie medycznym, jak przypadek chorobowy, prawnym - casus Kleist, casus Améry, wreszcie socjopsychologicznym), czy też ich pojedyncze akty mieszczą się w dwu paradygmatach szeroko pojętej nowoczesności: romantycznym i po-Zagładowym.

Alina Kowalczykowa, autorka szkicu o romantycznych samobójcach, przytomnie zauważa, że jakkolwiek ryzyko śmierci w przypadku, na przykład emisariuszy, było podobnie wielkie jak „w ówcześnie znanym berlińskim klubie samobójców, w którym przypadek wskazywał kolejnego wybrańca losu"18, nikt nie myślał o ewentualnym zgonie tajnego wysłannika jako o samobójstwie. Samobójstw mieszczących się w dyskursie heroicznym (śmierć Ordona) lub wynikających z kodeksu honorowego, „quasi-eutanazyjnych" nie utożsamia się bowiem z postawami samobójczymi; „gdyby nie dramatyczne sytuacje, idea samobójstwa

auf, um sich zu Fuß nach Dresden durchzuschlagen. In Berlin wird er zusammen mit dem Hauptmann von Ehrenberg und dem Leutnant von Gauvain - Pfuel hatte sich kurz vorher von ihnen getrennt - auf dem französischen Gouvernement, wo sie ihre Pässe unterschreiben lassen wollten, verhaftet; nach wiederholten Verhören in Wustermark bringt man die drei über Marburg, Mainz, Strassburg und Besançon auf das Fort de Joux bei Pontarlier; dort hält man sie hinter dreifachen Gittern in einem Gewölbe... ohne Licht und ohne Luft vier Wochen gefangen, bis sie, Anfang April, in das Kriegsgefangenenlager Châlons-sur-Marne weiterbefördert werden. Hier kann sich Kleist ziemlich frei bewegen und auch arbeiten, doch da er kein Geld hat, ist er ganz auf die Unterstützung seiner Kameraden angewiesen. Nach dem Friedensschluß zwischen Preußen und Frankreich am 9. Juli 1807 ergeht der Befehl zu seiner Entlassung. Am 14. August trifft er in Berlin, am 31. in Dresden ein. Wahrscheinlich hat er erst nach seiner Rückkehr erfahren, in welcher Gefahr geschwebt hatte: Die Festnahme war auf Grund eines Spionageverdachts erfolgt und Spione pflegten standrechtlich erschossen zu werden".

18 A. Kowalczykowa, Samobójcy romantyczni, „Ruch Literacki” 1983, nr 6, s. 434. Dalej skrót SR, wraz z numerem strony. Był to pierwotnie referat wygłoszony podczas konferencji Style zachowań romantycznych (6-7 grudnia 1982). Na brak nazwiska Heinricha von Kleista u Kowalczykowej zwraca uwagę Maria Cyranowicz w szkicu: Dlaczego von Kleist? Motyw samobójstwa Heinricha von Kleista w twórczości Marcina Świetlickiego, Jacka Podsiadty, Stefana Chwina i Manueli Gretkowskiej. W zbiorze: Literatura polska. 19902000, red. T. Cieślak, K. Pietrych, t. 1, Kraków 2003, s. 346-365. 
byłaby im [popełniającym je ludziom - K.K.K.] prawdopodobnie zupełnie obca" (SR, 432-433).

Czy Kleist umiera jak Werter, Chatertton ${ }^{19}$, Levittoux²0? Czy Améry, umierając w wieku 66 lat, 33 lata po wyzwoleniu z Auschwitz, zadaje sobie śmierć odroczoną jak Paul Celan, Primo Levi, Bogdan Wojdowski?

$\mathrm{Na}$ pierwsze $\mathrm{z}$ tych pytań negatywnie odpowiada Marcel Brion w połowie XX wieku, w tomie L'Allemagne romantique: „On remarquera d'abord, dans les événements qui ont précédé le suicide, l'absence de toute exaltation romantique, de tout égarement pathétique" (AR, 11). I dalej: „Cette mort n'était pas la suite d'un coup de tête ni d'un mouvement de désespoir. Depuis longtemps décidée, la résolution de mourir était née en eux au moment même où ils s'étaient vus pour la première fois, deux ans plus tôt, dans un salon de Berlin" (AR, 12)21. Brion nazywa śmierć Henrietty i Heinricha wykonaniem imperatywu vouloir mourir, dla nich równie naturalnego jak dla innych, być może naturalny pozostaje imperatyw vouloir vivre (AR, 13). To brzmi, oczywiście, jak rozważania Améry'ego o naturalności wolnej śmierci, zanotowane powyżej.

Podobną, przeczącą, odpowiedź daje, już na progu XXI stulecia Maria Janion: „Kleist-samobójca stał się emblematem, ale innym niż Werter, gdyż bohater powieści Goethego nie znał immanentnej ekstazy śmierci" (MJ, 349). Nie umiera ze względu na nieszczęśliwą miłość, ale wraz $\mathrm{z}$ dobrowolną towarzyszką swej Todeslust, chorą na raka Adolfiną Henriettą Vogel, żoną berlińskiego urzędnika rachuby, Louisa Vogla ${ }^{22}$. To śmierć w całym tego słowa znaczeniu podwójna, daty narodzin samobójców są zbliżone, data śmierci - oczywiście - jest ta sama: 1811, to śmierć

19 Tytułowy bohater dramatu Alfreda de Vigny z 1835 roku.

20 Wielka encyklopedia powszechna PWN, t. 15: kreteńska kultura - limitatio, Warszawa 2003, s. 493, s.v. „Karol Levittoux”: „ur. 1820, Kumelsk k. Kolna, zm. VII 1841, Warszawa, działacz niepodległościowy; związany z tajnym Stowarzyszeniem Ludu Polskiego, 1839 organizator tajnego sprzysiężenia skupiającego gł. młodzież gimnazjalną w Warszawie i Łukowie; 1841 aresztowany; więziony w Cytadeli warszawskiej, wskutek tortur i w obawie przed dalszymi przesłuchaniami popełnił samobójstwo przez samospalenie. Jego czyn został utrwalony w poezji (C. Norwid, W. Syrokomla) i malarstwie (A. Kozakiewicz).

$21 \mathrm{~W}$ swobodnym przekładzie: „Zwraca uwage najpierw, w zdarzeniach poprzedzających samobójstwo, nieobecność wszelkiej romantycznej egzaltacji, całego wzniosłego zbłądzenia” (AR, 11). I drugi fragment: „Ta śmierć nie była następstwem szalonego pomysłu ani porywu rozpaczy. [Śmierć] od dawna postanowiona, decyzja, by umrzeć narodziła się w nich w tej samej chwili, gdy spotkali się po raz pierwszy, dwa lata wcześniej, w salonie berlińskim" (AR, 12).

${ }^{22}$ Informację podaję za: L, 507, przypis 1 (list z 9 listopada 1811 do Marii von Kleist). Poeta próbował namówić na wspólne samobójstwo Marię von Kleist, ale ta wielokrotnie odmawiała; nie chciał umierać sam, bo ta śmierć miała być podobna do aktu miłosnego. 
symetryczna - oboje sobie nawzajem towarzyszą, żadne z nich nie musiało drugiej strony do tego czynu przekonywać, czy namawiać. Miało być to samobójstwo - jak akt wspólnej rozkoszy i jak dzieło sztuki. Janion nazywa je „rodzajem estetycznego spirytualizmu” (MJ, 353).

$\mathrm{Na}$ drugie pytanie odpowiedzieć trudniej. Wiadomo, że Améry'ego kusiły inne rodzaje śmierci niż ten, który wybrał. Kusił go skok z szesnastego piętra. „Jak będzie spadać moje ciało?” (JA, 189). Wiadomo też, że dość długo wykładał swą poetykę sformułowana samobójstwa (rozumianego jako Freitod, oczywiście) - najpierw w rozprawie o starzeniu się, potem w książce Podnieść na siebie rękę. To były jego otwarte Todesbriefe. A jednocześnie trudno odmówić tej śmierci semiotycznej precyzji (jakby wbrew, na przekór stochastyczności niedokonanej śmierci w Auschwitz): 33 lata po ocaleniu z obozu Zagłady, w 66. roku życia, w salzburskim hotelu, niedaleko miejsca urodzenia. Wolną śmierć, własną śmierć, wolną także dlatego, że niepodległą procedurom eutanazyjnym, można zatem potraktować jako samobójstwo immanentne (najpierw przygotowanie teoretyczne, samobójstwo intelektualisty, który był ofiarą Auschwitz, ale intelektualistą także był i nim pozostał). I taka śmierć zasadniczo różni się od dramatycznego skoku Paula Celana do Sekwany w rocznicę urodzin Hitlera, od Prima Léviego, który „zabił się po 45 latach w Auschwitz”, od Wojdowskiego, który odebrał sobie życie wiele lat po getcie.

Czy to znaczy, iż nie istnieją dwa zasadniczo różne paradygmaty samobójstwa, ten romantyczny i ten po Auschwitz? Istnieją. Ale paradygmat to nie ustawa norymberska. Mogę zadawać sobie śmierć na wiele sposobów; nie reguluje tego, na szczęście, żadna ustawa. Ten, kto zadaje sobie śmierć, może pozostać sobą w tym akcie ostatniej wolności. 